\title{
Screening tests for hepatitis B antigen and antibody in two colleges of education and studies on the relationship between nonspecific positive antibody tests and EB virus infection
}

\author{
K. G. RUPARELIA AND J. M. B. EDWARDS ${ }^{1}$ \\ From the Virus Reference Laboratory, Central Public Health Laboratory, Colindale Avenue, London NW9 5 HT
}

SYNOPSIS Sera from 627 students entering Colleges of Education between 1969 and 1972 were tested for hepatitis B surface antigen and antibody. One was found positive for antigen, none for antibody. Six of 15 positive Hepanosticon results and two positive Hepatest results occurred in sera which also gave positive heterophil antibody tests indicative of current or recent EB virus infection. One of these six sera was still positive in the Hepanosticon test after one absorption, and one of two Hepatests gave no positive reaction with the control cells. Eleven of 14 sera from cases of infectious mononucleosis gave positive Hepanosticon results and two were still positive after one absorption. Seven were positive in the Hepatest and only three of these were positive with the control cells. The control tests in the Hepanosticon and Hepatest do not clearly identify all false positives due to Paul Bunnell antibody. It is suggested that when a positive result in a passive haemagglutination test can be removed by absorption or if positive after absorption cannot be confirmed by other tests for hepatitis Bs antigen, the patient from whom the serum specimen was taken should be investigated for indications of current EB virus infection.

In order to study the incidence and carrier rate of hepatitis B (Australia antigen) in healthy young adults, tests were done on sera which had been taken from student volunteers shortly after entry to two residential Colleges of Education in Bedford. Between 1969 and 1972 The Epidemiology Research Laboratory of the Central Public Health Laboratory, Colindale had collaborated with the general practitioners and the Medical Department of the Colleges of Education to obtain serial serum specimens from college entrants and from cases of infectious mononucleosis in order to study the prevalence of infection with EB virus (University Health Physicians and Public Health Laboratory Service Laboratories, Joint Investigation, 1971). These sera had been stored and were available for the present study. It has been found that sera from cases of infectious mononucleosis give positive results in the passive haemagglutination tests due to the red cell agglutinins present. The results of tests for EB virus and heterophil antibody (Paul Bunnell) were already ${ }^{1}$ Requests for reprints to JMBE

Received for publication 24 February 1976 available, and in addition in this study EB virus IgM tests were performed, so it was also possible to study the relationship between EB virus infection and a positive hepatitis $B$ agglutination test.

\section{Material and methods}

Entry sera from 627 students were tested. In one college acute and convalescent blood samples were also taken from students presenting with suspected infectious mononucleosis. Some, but not all, of these had provided an entry serum. Initially, all the sera were tested for hepatitis B surface antigen (HBsAg) $N$ by passive haemagglutination tests (Hepanosticon $N$ by Organon Ltd). This is a test employing treated $\stackrel{\sim}{N}$ sheep cells coated with a thin layer of antibody to $\mathrm{C}$ HBsAg. Any sera found positive in the Hepanosticon test were retested after absorption with the absorbent supplied. This consists of treated sheep $\mathbb{\complement}$ erythrocytes coated with a gamma-globulin preparation not containing antibodies to HBsAg. Any sera reacting in the Hepanosticon test were also tested by another haemagglutination test (Hepatest 
Wellcome Research Laboratories). This test uses tanned turkey cells coated with purified horse antiserum to HBsAg. A parallel test is made with 'control cells' which are turkey cells coated with normal horse immunoglobulin. Sera giving consistent positive results for HBsAg were examined by electron microscopy (EM) and by radioimmunoassay (RIA) (Ausria II). All commercial tests were performed according to the instructions in the kit.

All sera were tested for HBsAg by counter immunoelectro-osmophoresis (CIEOP) as described by Pesendorfer et al (1970). At a later date, when the passive haemagglutination for antibody to hepatitis B surface antigen $\mathrm{HBsAb}$ (Virgo reagents) became available, the 254 sera from one college and also the sera giving positive or doubtful results in CIEOP from the other college were retested with this test.

The entry sera found positive in the Hepanosticon test were also tested for EB virus $\operatorname{IgM}$ and for heterophil antibodies, both indicators of current or recent infection with EB virus. The sera from the cases of infectious mononucleosis had already been tested for EB virus IgG antibody and for heterophil antibody in the university survey. In this study they were tested for EB virus IgM by the indirect immunofluorescence test. Methods used are described by Edwards and McSwiggan (1974).

\section{Results}

ENTRY SERA

Hepatitis Bs antigen tests

Table I shows the results of the 627 entry sera, 16 of

\begin{tabular}{llllll}
\hline & Hepanosticon & $\begin{array}{l}\text { After } \\
\text { absorption }\end{array}$ & Hepatest & RIA & EM \\
\hline $\begin{array}{l}\text { Positive } \\
\text { Negative }\end{array}$ & 611 & 2 & $4(1)^{1}$ & 1 & 1 \\
$\begin{array}{l}\text { Number } \\
\text { tested }\end{array}$ & 627 & 14 & 11 & 14 & 1 \\
\hline
\end{tabular}

Table I Antigen tests: Analysis of further hepatitis tests on 16 entry sera found positive by Hepanosticon

${ }^{1}$ Figure in brackets indicates a positive reaction with the control cells.

which were positive in the Hepanosticon test. Only two of these remained positive after one absorption. Because of an insufficient quantity of one serum only 15 of the 16 were tested by the Hepatest, and four of these were positive, including the two which had been found positive in Hepanosticon after absorption. Only one of these four also gave a reaction in the Hepatest control cells. These 15 were also tested by RIA and only one was found positive.
This one, which had been Hepanosticon positive after absorption and Hepatest positive, also showed HBsAg and Dane particles by electron microscopy.

\section{Hepatitis Bs antibody tests}

The 627 sera were tested for HBsAb by CIEOP initially. Of these, 612 were clearly negative. The results of the other 15 were difficult to read and were not reproducible. It was thought that this test is not valuable when sera have been stored for a prolonged period. At a later date 254 sera from one college were tested in the passive haemagglutination test (Virgo) for HBsAb. None of these was positive. Those sera from the other college giving positive or doubtful results in CIEOP were also tested in the passive haemagglutination test and found negative.

\section{Tests for EB virus infection}

The 16 sera positive in the Hepanosticon test were tested for EB virus IgM and for heterophil antibody (table II). Six were positive in the heterophil anti-

\begin{tabular}{lcccc}
\hline & Hepanosticon & $\begin{array}{l}\text { After } \\
\text { absorption }\end{array}$ & EB IgM & $\begin{array}{l}\text { Monospot/ } \\
\text { Paul Bunnell }\end{array}$ \\
\hline Positive & 16 & 2 & 3 & 6 \\
$\begin{array}{l}\text { Negative } \\
\text { Number }\end{array}$ & 0 & 14 & 13 & 10 \\
tested & 16 & 16 & 16 & 16 \\
\hline
\end{tabular}

Table II Analysis of infectious mononucleosis tests on 16 entry sera found positive by Hepanosticon

body test, and three of these were also positive for EB virus IgM. Further sera were available from these students, all taken at least six months later. Two out of nine were still Hepanosticon positive, but none of them was positive for EB IgM or heterophil antibody.

SERA FROM CASES OF INFECTIOUS MONONUCLEOSIS

Tests for hepatitis BsAg and EB virus

Acute and convalescent serum samples were available from 14 cases of infectious mononucleosis (table III) occurring between 1969 and 1972. Half of these sera showed EB virus IgG seroconversion from the pre-illness serum or a fourfold rise in titre during the illness. The other half had had no preillness serum taken and there already were high IgG titres in the acute specimens. However, all the sera from these cases were positive in the heterophil antibody test (Paul Bunnell), and all but one, which was not available for testing, of the acute sera were positive for EB virus IgM. The acute specimens from 11 of these cases gave positive Hepanosticon results, and two were still positive after one absorp- 


\begin{tabular}{lrrrrrr}
\hline & $\begin{array}{l}\text { Hepano- After } \\
\text { sticon }\end{array}$ & $\begin{array}{l}\text { absorp- } \\
\text { tion }\end{array}$ & & & & $\begin{array}{c}\text { Hepatest } \\
\text { phil } \\
\text { antibody }\end{array}$ \\
\hline Acute & & & & & & \\
Positive & 11 & 2 & $7(3)^{1}$ & 0 & 13 & 14 \\
$\begin{array}{l}\text { Negative } \\
\text { No. tested }\end{array}$ & 14 & 9 & 4 & 5 & 0 & 0 \\
$\begin{array}{l}\text { Convalescent } \\
\text { Positive }\end{array}$ & 3 & 0 & $2(2)^{1}$ & NT & 2 & 10 \\
$\begin{array}{l}\text { Negative } \\
\text { No. tested }\end{array}$ & 9 & 3 & 4 & NT & 4 & 0 \\
\hline
\end{tabular}

Table III Results of specimens from 14 cases of infectious mononucleosis

${ }^{1}$ Figures in brackets indicate positive reactions with the control cells.

tion. These two sera were those with the highest titre in the heterophil antibody test. Only three of the convalescent sera were positive.

Of the total 11 positive in the Hepanosticon test, seven were also positive in the Hepatest. Only three of these were also positive with the control cells. Five were tested in HBsAg RIA but all were negative.

\section{Discussion}

Of 627 sera from healthy students of average age 18, one serum only was found to contain hepatitis B antigen. The normal incidence among blood donors in the United Kingdom is 1 in 1000 so that is an expected proportion. It is known from this student's medical record that in childhood he had had multiple operations for correction of a congenital defect. He may well have required transfusion on these occasions and screening of blood donors did not begin in the UK until after he had entered university.

None of the 254 sera screened for antibody to hepatitis $B$ antigen by the passive haemagglutination test was positive even though some were CIEOP positive. All these sera had been stored for between four and six years and, although held at a temperature below $-20^{\circ} \mathrm{C}$ for most of that time, they were on more than one occasion thawed for testing and refrozen. It is probable that some of them were also contaminated, and this is a likely reason for tests in CIEOP which could not be confirmed.

Chicot et al (1975) record 577 Hepanosticon positive tests in approximately 140000 blood donors. They found 322 of these reactions were nonspecific, as judged by RIA (Ausria I) and neutralization, as well as by reversed passive haemagglutination (Raphades B), and 53 of these required more than one absorption to render them negative. In our survey there were 15 nonspecific Hepanosticon positive sera out of 627 , which is a rather higher proportion. This may be due to this sample coming from an age group that is particularly susceptible to infectious mononucleosis.
Our study also shows that of the 15 sera giving nonspecific positive results, six had a positive $\stackrel{0}{\vec{*}}$ heterophil antibody test and three of these were also 으․ positive for EB IgM. They were therefore likely to be $\Rightarrow$ convalescent from recent EB virus infection. It is $\stackrel{\oplus}{\oplus}$ known that EB virus infection in the university age group can occur either with or without characteristic $\frac{\bar{\sigma}}{\bar{N}}$ symptoms of infectious mononucleosis (University $\frac{\pi}{\sigma}$ Health Physicians and Public Health Laboratory $\unrhd$ Service Laboratories, Joint Investigation, 1971) and that heterophil antibody can be detected in those $\vec{\circ}$ without typical symptoms (Edwards and McSwiggan, 1974; Sutton et al, 1974). Two of these students gave $\vec{\omega}$ recent histories suggestive of infectious mono- $\frac{\Omega}{8}$ nucleosis when questioned at the time of sampling. ? From the 14 students known by the EB virus specfic ${ }_{0}$ tests to have infectious mononucleosis, sera from $11 \vec{\circ}$ were positive in the Hepanosticon test at some time $i$ during their illness and two of these were positive $\infty$ after one absorption. Seven were also positive by $ᄋ$ Hepatest, and four of these gave no reaction with the control cells. The agglutinin receptors on the sheep $\bigcirc$ cells used in the Hepanosticon test are not obscured $\stackrel{?}{0}$ by the adsorbed HBsAb. Human sera may contain a variety of sheep cell agglutinins, such as Forssman antibody and the heterophil antibody of infectious $\vec{\theta}$ mononucleosis. A full heterophil antibody tes o preferably using horse erythrocytes, with differenti递 absorption by guinea-pig kidney and ox cells, wi reveal those sera in which the agglutinating factor is due to the heterophil antibody positive in EB virus infection (Davidsohn and Henry, 1969). Liver in- $\stackrel{\mathbb{D}}{\complement}$ volvement in cases of infectious mononucleosis is $\overrightarrow{\vec{A}}$ common. Clinical jaundice occurs in $8-10 \%$ of $\frac{0}{3}$ cases, and liver function tests are abnormal in 85$100 \%$ (Carter and Penman, 1971). Quite frequently the indication for requesting a test for hepatitis Bs antigen is a pyrexia of unknown origin with abnormal? liver function tests. It would therefore seem worth- $\frac{5}{3}$ while considering the diagnosis of $\mathrm{EB}$ virus infection when a report is received stating that the Hepano- $O$ sticon test or Hepatest was positive but negative after absorption and control test, or, if still positive, 으 unconfirmed by RIA or enzyme test.

Sera from young adult staff working in special units are often screened for hepatitis $B$ antigen, and $N$ any false positive result is a particular problem with such people often causing investigation of serial 0 sera. If a diagnosis of recent or current subclinical $\omega$ EB virus infection can be made by a positive hetero- 2 phil antibody test the cause of the false positiveco reaction will remove unnecessary anxiety.

Our thanks are due to the other members of the $\frac{T}{0}$ University Health Physicians and Public Health $\frac{\vec{\Phi}}{\mathbb{D}}$ Laboratories for allowing us to use the results of the $\stackrel{\odot}{\oplus}$ 
EB virus antibody survey; to $\mathrm{Mr} \mathrm{B}$. Cohen for helpful advice and electron microscopy examinations; and to Dr Pereira and Mrs Joy for help in preparation of this report.

\section{References}

Carter, R. L., and Penman, H. G., eds. (1971). Infectious Mononucleosis, pp. 55-57. Blackwell, Oxford.

Chicot, D., Wright, R., Brotman, B., and Prince, A. M. (1975). Hepanosticon in screening for HBsAg. (Letter.) Lancet, $1,345$.

Davidsohn, I., and Henry, J. B., eds. (1969). Todd-Sanford Clinical Diagnosis by Laboratory Methods, 14th edition.
Saunders, Philadelphia.

Edwards, J. M. B. and McSwiggan, D. A. (1974). Studies on the diagnostic value of an immunofluorescence test for EB virus-specific IgM. J. clin. Path., 27, 647-651.

Pesendorfer, F., Krassnitzky, O., and Wewalka, F. G. (1970) Viral hepatitis and tests for the Australia (hepatitis associated) antigen and antibody. Bull. Wld Hlth Org., 42, 974-975.

Sutton, R. N. P., Marston, S. D., Almond, E. J. P., Reynolds, K. and Pounds, F. J. (1974). Asymptomatic infection with EB virus. J. clin. Path., 27, 97-100.

University Health Physicians and Public Health Laboratory Service Laboratories, Joint Investigation (1971). Infectious mononucleosis and its relationship to EB virus antibody. Brit. med.J., 4, 643-646. 